\title{
ARTIKELEN
}

\section{Positieve veiligheid. Een inleiding}

\author{
Marc Schuilenburg \& Ronald van Steden
}

\section{Aanleiding}

Criminologen vatten veiligheid meestal op als een negatief begrip. Eigenlijk gaat het hen primair om onveiligheid in relatie tot overlast, criminaliteit, terrorisme en unheimische gevoelens van mensen. Lucia Zedner (2009: 12) meent dat het begrip veiligheid in moderne samenlevingen als vanzelf wordt gekoppeld aan externe dreigingen, waaronder ' $9 / 11$ ', (georganiseerde) criminaliteit en een permanente noodtoestand, zoals die nu in diverse Europese landen van toepassing is om de autoriteiten meer juridische armslag te geven in de strijd tegen het terrorisme. Deze toch behoorlijk gestreste politieke en maatschappelijke situatie heeft de criminologie als vakgebied nationaal en internationaal geen windeieren gelegd. Het vakgebied is booming business - een trend die samenvalt met, misschien zelfs een effect is van,

'the rising prominence of crime within the mundane culture and political programmes of a number of western societies, and the increasing drift towards more punitive solutions to crime and more intrusive approaches to security issues' (Loader \& Sparks, 2011: 11).

De sterk toegenomen aandacht voor onveiligheid blijft niet beperkt tot de academische wereld. Actueel sociaal veiligheidsbeleid, dat deels door criminologen wordt gevoed en dat criminologisch onderzoek op zijn beurt ook weer aanjaagt, staat bol van verwijzingen naar 'controle', 'repressie', 'tegenhouden', 'vergelden', 'terugdringen' en 'bestrijden'. Om een idee te geven: in het Regionaal Veiligheidsplan 2015-2018 van de gemeente Amsterdam valt het woord 'aanpakken' ruim tweehonderd keer.

Het gevolg is dat een ongebreidelde 'bestrijdingsbegeerte' - Herman Bianchi (1958: 4) muntte deze term al in de jaren 1950 - zich van de samenleving meester heeft gemaakt. Zo breidt camerabewaking zich steeds verder uit (Norris et al., 2002), dringen digitale surveillancetechnieken diep door in het dagelijks leven (Lyon, 2001), wordt er om hogere minimumstraffen gevraagd (Van Wingerden, 2011), steekt het straffende bestuursrecht ('quasi-strafrecht') steeds meer de kop op (Schuilenburg, 2009), dijen politiebevoegdheden, zero tolerance en bijbehorende maatregelen zoals preventief fouilleren almaar uit (Schuilenburg \& Van Swaaningen, 2013), gelden er steeds meer verschillende vormen van gebiedsverboden (Schuilenburg \& Van Steden, 2014a), neemt het aantal particuliere beveiligers en buitengewoon opsporingsambtenaren toe (Van Steden, 2013) en schieten buurtwachten (Lub, 2016) als paddenstoelen uit de grond. Eenzelfde tendens zien 
we terug in het gebruik van militair jargon in het veiligheidsbeleid, dat spreekt over 'frontlijnwerkers' (Moors \& Bervoets, 2013), 'stadsmariniers' (Tops, 2011) en 'interventieteams' (Schuilenburg \& Dijkstra, 2011) die voor en achter de voordeur orde op zaken komen stellen in de onveilige jungle van het alledaagse leven. Burgers trekken zich daarbij het liefst terug achter de behaaglijke muren van afgeschermde woonwijken (Schuilenburg \& Van Steden, 2015), winkelcentra, pretparken, Business Improvement Districts en andere afgeschermde stedelijke gebieden (Crawford, 2011). Voor wie het betalen kan, is veiligheid een consumptiegoed geworden.

De hiervoor beschreven 'securitisering' (Schuilenburg, 2015) van de samenleving en 'militarisering' (Davis, 1992, 1998; Graham, 2010) van de publieke ruimte leiden tot een 'marginalisering' (Wacquant, 2008) en 'uitsluiting' (Young, 1999) van kwetsbare, maar niettemin gevaarlijk geachte, groepen. Hangjongeren, daklozen, verslaafden en vluchtelingen zijn hier vaak het lijdend voorwerp van. Met een variatie op de Nederlandse gevoelstemperatuur dat 'het met mij goed, maar met ons slecht' gaat, vallen zorgen over hufterigheid, overlast en criminaliteit samen met de wens om vooral 'de ander' te disciplineren en te controleren. Het merkwaardige van dit alles is dat de hier beschreven trends plaatsvinden in een tijd dat criminaliteitscijfers in westerse landen blijven dalen en het aantal mensen dat zich (wel eens) onveilig voelt steeds verder afneemt (CBS, 2015). Bovendien gaat men er erg gemakkelijk aan voorbij dat veiligheid een dynamisch en veelzijdig begrip is dat niet alleen harde kanten kent, maar zich net zo goed organiseert rondom zachtere principes van 'verbondenheid', 'geborgenheid', 'zorg' en 'herstel' (Schuilenburg et al., 2014; Van Steden \& Hoogland, 2013). Anders gezegd: te snel wordt vergeten dat veiligheid naast negatieve connotaties ook positieve betekenissen heeft.

In dit themanummer willen we de positieve betekenissen van veiligheid nader belichten. Anders dan publicaties die geheel anti-security (cf. Neocleous \& Rigakos, 2011) zijn, benadrukken wij in de volgende paragrafen de meerstemmigheid van het veiligheidsconcept. Aan de ene kant hangt veiligheid samen met een negatief mensbeeld dat het kwade benadrukt en uit vrees voor een oorlogstoestand de overheid vraagt om te straffen. Aan de andere kant bestaan er allerlei alternatieve vertogen die wijzen op het sociaal goed(e) dat veiligheid belichaamt, maar die minder tot geen aandacht krijgen binnen de sociale wetenschappen, de criminologie in het bijzonder (Schuilenburg \& Van Steden, 2014b). ${ }^{1}$ Zo worden in vakgebieden als de sociobiologie en de Internationale Betrekkingen discussies gevoerd over het belang van positieve noties zoals altruïsme, empathie, peace building en human security voor het doen opbloeien van samenlevingen. Doorredenerend vanuit deze vertogen komen we tot een omschrijving van 'positieve veiligheid' en gaan we in op de samenhang tussen 'positieve veiligheid', beleid en ethiek. We

1 Niettemin zijn er ook in de criminologie verschillende aanknopingspunten te vinden voor een meer positieve insteek op veiligheid. Een volledig overzicht hiervan is onmogelijk te geven, maar een goed voorbeeld is de kritische criminologie (zie het interview met Jacqueline de Savornin Lohman door René van Swaaningen in dit nummer) en meer in het bijzonder het werk van Louk Hulsman. Zo pleit Hulsman in 'Participatie van de gemeenschap bij de preventie van criminaliteit' voor 'positieve manieren van sociale controle' (2011: 205) bij de aanpak van criminaliteit. 
sluiten af met een introductie van de bijdragen aan het themanummer die de term 'positieve veiligheid' van een empirische lading voorzien.

\section{Natuurtoestand}

Om een goed idee te krijgen wat onder de term 'positieve veiligheid' moet worden verstaan, is het nodig om een kleine excursie naar het verleden te maken. Op deze manier kan het huidige debat over controle en straffen, dat zich doorgaans afspeelt op een vrij praktisch niveau, worden voorzien van een meer theoretische basis die we vervolgens met nieuwe - positievere - impulsen en inzichten willen uitbreiden. Daarvoor is het allereerst nodig terug te gaan naar het klassieke werk Leviathan uit 1651. In dat boek legitimeert Thomas Hobbes de opdracht van de Staat om zijn onderdanen een vredig en veilig leven te geven vanuit het 'natuurlijke' eigenbelang van de mens. Om het onderlinge geweld dat uit een (hypothetische) natuurtoestand voortkomt te beteugelen, komen mensen volgens Hobbes vanzelf uit op de gezamenlijke instelling van een overheid die een einde moet maken aan een situatie van totale anarchie. In deze chaotische situatie, zo schrijft Hobbes in de bekendste passage van zijn boek,

'is er geen plaats voor doelgerichte arbeid, want het is niet zeker dat deze resultaat zal hebben; er is dan ook geen landbouw, geen scheepvaart, en geen gebruik van goederen die over zee kunnen worden aangevoerd; geen architectuur; geen werktuigbouw, om dingen te verplaatsen en te verwijderen die veel kracht vergen; geen kennis van het aardoppervlak; geen tijdrekening; geen beeldende kunst; geen letterkunde; geen maatschappelijk leven; en, wat het ergste is, een voortdurende angst voor, en dreiging van een gewelddadige dood; het menselijk bestaan is er eenzaam, armoedig, afstotelijk, beestachtig en kort.' ([1651] 2007: 164)

Om niet terug te vallen in de natuurtoestand en de burgers een comfortabel leven te laten leiden - een leven dus 'buiten' of 'zonder' gevaar - handhaaft de Staat de veiligheid met alle middelen die hij tot zijn beschikking heeft. Deze vorm van machtsuitoefening, ook wel een 'juridische machtsvorm' (Foucault, 1975) genoemd, schraagt een soevereine staatsmacht die zowel extern - het leger - als intern - politie en Openbaar Ministerie - gewelddadige en straffende bevoegdheden heeft. De consequentie hiervan is dat het denken over sociale veiligheid en veiligheidsbeleid al snel wordt vernauwd tot een kwestie van wetshandhaving en het nemen van strafrechtelijke maatregelen.

De beschreven natuurtoestand speelt niet alleen in de politieke filosofie van Hobbes een centrale rol. Ook andere, belangrijke filosofen uit de Verlichting, waaronder Cesare Beccaria en John Locke, baseren hun gedachtegoed op de aanname van een oorspronkelijke wereld waarin mensen leven zonder statelijk verband met als gevolg dat daar een 'oorlog van allen tegen allen' heerst. Dat de invloed van Hobbes op deze denkers zeer aanzienlijk was, blijkt uit Beccaria's Over misdaad en straffen dat voor het eerst in 1764 werd gepubliceerd. Net als 
Hobbes vertrekt Beccaria, wiens visie op de legitimiteit van de statelijke machtsuitoefening en de effectiviteit van straffen nog steeds zeer invloedrijk is in het huidige denken over sociale veiligheid, vanuit de leer van het maatschappelijk verdrag dat een einde maakt aan een anarchistische natuurtoestand, die, zo schrijft hij, 'men nuchterweg [moet] beschouwen als een bestaand feit' ([1764] 1982: 33). Tussen Locke en Hobbes bestaan er grotere verschillen in inzicht over wat een 'natuurtoestand' precies inhoudt. Zo is de natuurtoestand bij Locke lang niet zo gewelddadig als bij Hobbes. Ook maakt Locke onderscheid tussen een 'natuurtoestand' en een 'oorlogstoestand', een verschil dat bij Hobbes niet voorkomt. Maar ondanks deze verschillen gaat ook bij Locke de natuurtoestand vooraf aan de totstandkoming van een burgerlijke samenleving onder staatsgezag. Daarbij lijkt zijn beschrijving van de natuurtoestand op die van Hobbes wanneer Locke spreekt over de vele ongemakken van zo'n toestand. Een belangrijk argument van Locke dat pleit voor de overgang van een natuurtoestand naar een burgerlijke samenleving is de rol die Staten en wetten spelen. Deze Staten en wetten dragen volgens Locke bij aan de waarborging en maximalisatie van de 'natuurlijke vrijheden' die burgers bezitten. Dit brengt voor burgers weliswaar een verlies van 'natuurlijke vrijheid' met zich mee, zij zullen toch instemmen met de oprichting van een Staat, omdat die hun vrijheid optimaal kan beschermen (Locke, 1988). Zonder wet is er namelijk geen vrijheid, zo meent Locke.

Relevant bij dit alles is dat de door Hobbes beschreven natuurtoestand zich kenmerkt door wederzijds wantrouwen tussen mensen. Dat wantrouwen voedt zich door de menselijke gewoonte elkaar altijd te slim af te willen zijn. Het grondmotief van het handelen van de mens draait dus om eigenbelang. De mens is niets meer dan een egocentrisch wezen dat op een agressieve manier streeft naar zelfbehoud en naar bevrediging van zijn individuele behoeften. Spreekt Hobbes over menselijke hartstochten, dan noemt hij vooral negatieve gemoedsbewegingen zoals begeerte, vrees, angst en haat. Daarbij is het mensbeeld bij Hobbes sterk negatief, bijna animaal, ingekleurd. Hobbes heeft het dan ook over de mens in termen van het Romeinse spreekwoord homo homini lupus est: 'de mens is voor andere mensen een wolf'. Hiermee neemt hij afstand van het aristotelische mensbeeld dat de mens van nature een sociaal en politiek gemeenschapsdier is.

Het negatieve en deterministische mensbeeld dat Hobbes schetst, heeft niet alleen grote invloed uitgeoefend op filosofen zoals Cesare Beccaria en later Friedrich Nietzsche met zijn 'wil tot macht'. Zijn schaduw strekt zich ook uit over de biologie wanneer Charles Darwin wijst op een 'survival of the fittest' en over de psychologie van Sigmund Freud waarin de aangeboren 'agressiedrift' van de mens centraal staat. De vraag is echter of het sombere mensbeeld van Hobbes en de daarmee samenhangende maatschappijvisie voldoende grond hebben, gelet op (nieuwe) wetenschappelijke inzichten over 'positieve gedragseigenschappen' van mensen. Zijn beloning en straf (met het strafrecht voorop) altijd nodig om menselijk gedrag van buitenaf te sturen en hen veilig en vredig te laten samenleven? 


\section{Positieve gedragseigenschappen}

De hiervoor geschetste theoretische basis van de natuur- of oorlogstoestand, en het bijbehorende beeld van de mens als agressief en egoïstisch ingesteld wezen, is niet onomstreden. Behalve bij Aristoteles die wees op de mens als politiek gemeenschapsdier, komen positiever ingestoken mensbeelden ook terug in onder meer het werk van Jean-Jacques Rousseau en David Hume. Zo beargumenteerde Rousseau ([1755] 2003) dat de mens van nature goed is, maar dat de beschaving hem slecht heeft gemaakt. Hume (2011) stelde op zijn beurt dat in de mens niet alleen elementen zitten van de wolf en de slang, maar ook van de duif (zie ook: Cliteur, 2007; Claessen, 2015). Volgens verschillende auteurs lijdt het daarom geen twijfel dat de eerder geschetste negatieve uitgangspunten in het denken van Hobbes moeten worden geproblematiseerd of zelfs moeten worden vervangen door andere uitgangspunten.

Zo is er op dit moment een flink wetenschappelijk debat gaande over empathie en altruïsme. Wijzelf hebben in dit verband gewezen op inzichten uit de - niet geheel onomstreden - sociobiologische literatuur (Schuilenburg \& Van Steden, 2014a). Vooral de bekende Nederlandse primatoloog en etholoog Frans de Waal zet de veronderstellingen achter het denken van Hobbes en diens nazaten verregaand onder druk. In The Age of Empathy schrijft De Waal (2009) dat wie het sociale gedrag van dieren als chimpansees en bonobo's onderzoekt, tot de ontdekking komt dat samenwerking tussen dieren heel normaal is en dat veel van de verworvenheden van de menselijke cultuur, waaronder rechtvaardigheid en empathie, diep zijn verankerd in evolutionaire processen. Op basis van zijn onderzoek stelt De Waal dat dergelijke positieve gedragseigenschappen in velerlei opzichten al terug zijn te vinden in het gedrag van primaten. Hij noemt dit de 'aap in ons'. Volgens De Waal is Hobbes' these van een gewelddadige natuurtoestand dan ook 'a questionable statement about our own species based on false assumptions about another species' (2009: 4). Tevens noemt De Waal het idee dat onze voorouders hun vrijheid opgaven voor veiligheid en een gemeenschapsleven een onjuiste oorsprongsmythe. Veiligheid was volgens hem juist de allerbelangrijkste reden voor het sociaal samenleven van onze voorouders.

Hieruit volgt dat gemeenschapsleven niet ontstaat uit het afsluiten van een sociaal contract, zoals onder meer beschreven door Hobbes en Beccaria. Integendeel, gemeenschapsleven vormt de natuurlijke basis van menselijk bestaan. Hiermee herinnert De Waal ons eraan dat een samenleving niet is gebaseerd op een wederzijds voordeel, maar op organische verbindingen. En binnen deze verbindingen zijn positieve gedragseigenschappen, waaronder 'empathisch vermogen', 'zorg voor de ander' en 'geven van gerichte hulp', belangrijke dimensies bij de vorming van gemeenschappelijke verbanden. Vanzelfsprekend kan de mens ook agressief en gewelddadig zijn, maar dat moet ons niet blind maken voor het feit dat empathisch gedrag evenzogoed door de natuur is voorgeprogrammeerd. In zijn mensbeeld grijpt De Waal daarmee terug op de communitaristische visie van Aristoteles, voor wie de mens van nature een sociaal wezen is (zie ook: Gardner, 2003). De grondgedachte van Aristoteles is niet die van de vrije en autonome, maar van de sociale en politiek georiënteerde mens (al bleef die mens in de Griekse polis 
beperkt tot mannen van een zeker welvaartsniveau). Voor hem zijn mensen altijd in zekere mate gebonden aan de normen en waarden van gemeenschappen - het gezin, de buurt, de natie - waartoe zij behoren en waarin het leven zich ontplooit. Ook andere auteurs zijn kritisch over het hobbesiaanse beeld van de mens als 'beestachtig dier'. Boeddhist en filosoof Matthieu Ricard, zoon van de bekende Franse denker Jean-François Revel, weerlegt in Altruïsme (2005) de aanname dat mensen door en door egoïstische monsters zouden zijn, van nature geneigd tot geweld en rivaliteit, en onder alle omstandigheden gericht op het najagen van hun persoonlijke belangen. Op basis van talrijke studies stelt Ricard dat er weinig tot geen wetenschappelijk bewijs is voor de gewelddadige aard van de mens. Natuurlijk pleegt de mens geweld; hij moordt en rooft door de geschiedenis heen. Tegelijk is het volgens Ricard een historische denkfout om zulk gedrag, dat dikwijls beperkt blijft tot persoonlijke conflicten, allemaal te categoriseren onder de noemer van een alomtegenwoordige (burger)oorlog. Met de aannames van Hobbes in zijn achterhoofd stelt Ricard vast dat we "het geloof in een sinds mensenheugenis brute, bloeddorstige en instinctief tot geweld geneigde mensheid moeten laten varen' (2015: 468). In de natuurtoestand gaat het niet zozeer om strijd en agressie, maar, zo meent Ricard met De Waal, om samenwerking en vreedzaam samenleven. Dit alles staat in schril contrast met de eerder geschetste negatieve affectenleer van Hobbes. Zoals eerder aangestipt, heeft Hobbes het veel minder, of zelfs in het geheel niet, over de mogelijkheid van positieve gedragseigenschappen - empathie, genegenheid en liefde - die mensen tentoonspreiden. Schrijft Hobbes eens over de liefde, dan ventileert hij een vrij materialistische opvatting door liefde gelijk te stellen aan begeerte, met als enige verschil dat we met 'begeerte de afwezigheid van het object aangeven, en met liefde meestal de aanwezigheid daarvan' ([1651] 2007: 96).

In het verlengde hiervan wijzen andere auteurs erop dat individueel en collectief geweld de laatste duizend jaar voortdurend afneemt. Zeker de laatste zestig jaar is dat het geval. Ondanks het voortbestaan van wrede conflicten zijn geïnstitutionaliseerde vormen van geweld (denk aan wrede straffen, slavernij en executies), alledaags geweld tegen kwetsbare groepen zoals vrouwen, kinderen, dieren en homoseksuelen, en geweld in de vorm van oorlogen en etnische zuiveringen wereldwijd afgenomen. In The Better Angels of Our Nature (2011) schrijft evolutionair psycholoog Steven Pinker deze afname van geweld toe aan verschillende oorzaken, waaronder een groeiende nadruk op de menselijke rede, een groter moreel gevoel en een sterkere nadruk op empathie. In tegenstelling tot De Waal, die meent dat empathie een neurologisch en evolutionair verankerd effect is, stelt Pinker dat empathie voortkomt uit een identificatie met de ander - en dus een 'reflectief affect' is (Oosterling, 2013: 378). Roman Krznaric werkt in Empathy (2014) dit idee verder uit wanneer hij beargumenteert hoe empathie menselijke banden creëert die het leven de moeite waard maken. En in Together (2012) maakt Richard Sennett een instructief onderscheid tussen sympathie ('een warme emotie') en empathie ('een koele emotie'). Terwijl sympathie partij kiest voor iemand en zich daarmee identificeert, geeft empathie ruimte aan nieuwsgierigheid naar de ander, aan dialoog, aan openheid en aan de mogelijkheid van andere (nietgewelddadige) oplossingsrichtingen. Hoe verschillend de invalshoeken van deze 
auteurs ook zijn, ze delen met elkaar een pleidooi voor menselijk samenleven en samenwerken. Dat is volgens hen de sleutel tot sociale binding en een veilige gemeenschap.

\section{Internationale Betrekkingen over positive security}

Over de betekenis en vorming van 'veilige gemeenschappen' is nergens zo systematisch nagedacht als in het vakgebied van de Internationale Betrekkingen. Ons doel is niet om dit hele debat in al zijn finesses dunnetjes over te doen (zie voor een literatuuroverzicht: Crawford, 2014). Wel willen we hieronder met enkele pennenstreken de hoofdlijnen van dat debat neerzetten om zo te komen tot een positieve invulling van het veiligheidsbegrip.

Dat denken begint al eind jaren 1960 als Johan Galtung (1969) het onderscheid tussen positieve en negatieve vrede introduceert. Met zijn onderscheid oefent Galtung kritiek uit op de aanname dat vrede niet meer is dan de afwezigheid van oorlog of gewapend conflict. Volgens hem zijn positieve condities, waaronder een stabiele economie, de beschikbaarheid van voldoende voedsel en schoon drinkwater, een gedegen onderwijsstelsel en functionerende democratische instituties, eveneens voorwaarden voor, en uitkomsten van, duurzame vrede. Hierbij zij opgemerkt dat de adjectieven 'positief' en 'negatief' naar iets anders verwijzen dan naar het onderscheid tussen 'goed' versus 'slecht'. Negatieve vrede verwijst slechts naar een negatie, terwijl positieve vrede het belang van sociale rechtvaardigheid verdedigt als constituerend voor stabiele en geweldloze samenlevingen (Waever, 2008). Positieve vrede legt, kortom, vormende en funderende verbindingen met individueel en gemeenschappelijk welzijn.

Voortbouwend op bovenstaand inzicht dat vrede en veiligheid naast militaire middelen eveneens heilzame economische, politieke en culturele condities in een land en in de wereld veronderstellen, introduceren de Verenigde Naties in 1994 de term human security. De kern van dit begrip houdt in dat veiligheid in de eerste plaats niet met Staten, maar met mensen moet worden verbonden. Hiermee vertrekt human security vanuit een bottom-up benadering, 'implying a redirection of traditional security policies' (Den Boer \& De Wilde, 2008: 11) in de richting van het creëren van economische voorspoed, politieke zeggenschap en een democratische rechtsorde voor iedereen. Jon Barnett en Neil Adger (2007) voegen aan dit rijtje een ecologische dimensie toe. Huidige en toekomstige generaties hebben recht op een schoon milieu, omdat vervuiling, uitdroging en ontbossing niet alleen slecht zijn voor mensen zelf, maar ook oorlogen tussen en binnen Staten kunnen uitlokken.

Reflecties op human security geven een evident normatieve lading aan wetenschappelijke discussies over veiligheid en sijpelen tevens door in beleid dat om pragmatische en morele redenen een grotere betekenis is gaan toekennen aan menselijke behoeften in de internationale politiek. Denk aan verdragen die het plaatsen van landmijnen moeten tegengaan, de roep om de bescherming van burgers in oorlogsgebieden en pogingen om de wapenhandel beter te reguleren (cf. Newman, 2016). Toch kleven er aan human security ook duidelijke nadelen. 
Behalve dat de term vanwege zijn breedheid nogal amorf is (Paris, 2001), blijven definities in het negatieve steken. Human security gaat in essentie om 'freedom from want' en 'freedom from fear' teneinde 'freedom to live in dignity' te bewerkstelligen (www.un.org/humansecurity). Wat veiligheid in positieve zin is, blijft daarmee onderbelicht.

Bill McSweeney (1999) probeert op dit punt meer helderheid te verschaffen door de introductie van zijn op Galtung geïnspireerde onderscheid tussen positive security en negative security. In zijn ogen verwijst veiligheid in positieve zin naar

'a quality or a relationship, grounded in human needs, which encourages confidence in the participants that their legitimate values are protected in a manner compatible with the capacity of others to do likewise' (1999: 100).

McSweeney maakt zo duidelijk dat veiligheid, in lijn met gezondheid, meer omvat dan 'niet ziek zijn' dan wel 'kwetsbaar zijn voor externe risico's, gevaren en dreigingen'. Het gaat ook om het doen floreren van samenlevingen en het emanciperen van minderheden. Onderlinge relaties aangaan en 'feminiene waarden' (Roe, 2014) naleven die verder gaan dan onmiddellijke persoonlijke behoeftebevrediging en puur overleven moeten bijdragen aan een meer op zorg, empathie en solidariteit gestoelde menselijke verhoudingen. Een democratische rechtsstaat die mensenrechten respecteert en pluriforme levenswijzen insluit, is hierbij een onmisbare randvoorwaarde (Loader \& Walker, 2007; Roe, 2008).

Dit alles betekent dat het belang van wetten en regels niet helemaal moet worden uitgevlakt, maar juridische contracten zijn niet het enige instrument waar de legitimiteit van een overheid op stoelt. Niettegenstaande alle onvolkomenheden, misverstanden, falend beleid en stroperige bureaucratie dragen democratische overheden noties uit van 'vrijheid, gelijkheid en broederschap' ter bevordering en onderhoud van vertrouwen, gemeenschapszin en prettig samenleven. De sociale veiligheid die zich 'binnenin' dit onderlinge vertrouwen bevindt, wordt echter niet alleen afgedwongen door straffen en belonen. Veiligheid vloeit ook voort uit positieve (humane) affecten die eigen zijn aan de mens. Inmiddels sijpelen deze inzichten door naar criminologische studies over de 'alledaagse veiligheid' (Crawford \& Hutchinson, 2015) van menselijke routines, emoties en praktijken. De volgende paragrafen gaan daarom in op de vraag hoe die inzichten kunnen worden vertaald naar een positieve definitie van veiligheid, met name in relatie tot een nieuwe ethiek van veiligheid.

\section{Positieve veiligheid}

Veiligheid is een veelzijdig en multi-interpretabel begrip. Aan de ene kant bevindt zich het gedachtegoed van denkers zoals Hobbes en Beccaria die vertrekken vanuit een negatieve invulling van (on)veiligheid die samenhangt met een chaotische natuurtoestand. Het politieapparaat en het strafrecht zijn vervolgens de belangrijkste instrumenten om een 'oorlog van allen tegen allen' te voorkomen (Wood \& Shearing, 2009; Hallsworth \& Lea, 2011). Dit betekent dat het bestrijden van cri- 
minaliteit in het teken staat van een overheid die (potentiële) daders met leedtoevoeging dreigt als zij de wet overtreden. Geweld, of dreiging met geweld, door de overheid is dus noodzakelijk om niet terug te vallen in een oorspronkelijke toestand van geweld waarin mensen zich bevinden. Het hiermee verbonden mensbeeld vat de mens op als een van nature kwaadaardig en gevaarlijk wezen dat vooral wordt voortgedreven door negatieve gemoedsbewegingen, waaronder vrees, angst en haat.

Aan de andere kant hebben we inzichten besproken van De Waal en Ricard die een positiever mensbeeld voorstaan waarbinnen plaats is voor empathie, compassie en altruïsme. Hun inzichten sluiten aan bij een positieve invulling van veiligheid, die erop wijst dat mensen sociale wezens zijn en in sociale verbanden leven. Dit aristotelische perspectief, waarin de mens voor zijn (voort)bestaan en vervolmaking de ander en de gemeenschap nodig heeft, geeft meer ruimte aan het belang van bescherming door elkaar dan Hobbes en Beccaria, die voornamelijk oog hebben voor hoe mensen zich het beste tegen elkaars egocentrische en gewelddadige neigingen kunnen beschermen. Ook al leven we in een 'vloeibare wereld' (Bauman, 2000) zonder duidelijke sociale, morele, religieuze en fysieke grenzen, mensen blijven contact en verbinding zoeken op plekken en via praktijken waarbinnen ze zich prettig en thuis voelen. De overheid en non-gouvernementele organisaties hebben hierbij een taak in het stimuleren van inclusieve sociale verbanden tussen burgers van allerlei snit.

Dit inzicht sluit aan bij de etymologie van het woord 'veiligheid' binnen het Nederlandse taalgebied. Het Middelnederduitse 'velich' en het Oudfriese 'felig' hangen niet enkel samen met 'zonder gevaar' zijn, maar verwijzen eveneens naar 'trouw', 'betrouwbaar' en 'vriendelijk' (Van Zuijlen, 2008: 12). Vermoedelijk gaan de begrippen 'veilig' en 'beschut' oorspronkelijk terug naar de term felich, waarbij vooral de betekenis van 'beschutting zoeken' leidt naar connotaties in de sfeer van 'dierbare' contacten tussen mensen. Dezelfde betekenisaspecten keren terug in het Duitse Geborgenheit en het Nederlandse 'geborgenheid', woorden die in het Engels meestal met 'security' worden vertaald. Geborgenheit geeft echter een positievere lading aan veiligheid, in de zin dat het hier primair gaat om het gevoel dat je op een plek bent die onderdak en beschutting biedt (Hutta, 2008). Vertrouwen geven en vertrouwen krijgen binnen een 'shared space' waar mensen zich 'thuis' weten (Van Steden et al., 2010; Van Marle, 2015), zijn daarom een belangrijk onderdeel van positieve connotaties die het concept veiligheid biedt.

In het verlengde hiervan is ook aandacht voor het Latijnse woord voor veiligheid - Securitas - op zijn plaats. Securitas is opgebouwd uit se ('zonder'), cura ('zorg') en tas (een staat van 'zijn'). John Hamilton (2013) toont in zijn filologische studie Security aan dat 'cura' een dubbele betekenis heeft. Allereerst kan 'zonder zorg zijn' duiden op 'zonder onrust' of 'zonder angst' leven. Deze betekenis voert terug op het eerder door ons beschreven negatieve mensbeeld van Hobbes, waarin veiligheid wordt opgevat als het wegnemen van 'pijn' of 'gevaar' (se-cura). Zo bezien heeft cura betrekking op alles wat voor onrust kan zorgen. Mensen zijn dan slechts veilig wanneer ze geen 'pijn' of 'gevaar' kennen. Maar, zo gaat Hamilton verder, cura kan ook positief worden uitgelegd in termen van 'oplettendheid' en 'ijver'. Het gaat dan om een vorm van 'zorg' die je aan iets of aan iemand besteedt. 
Dit houdt in dat cura zowel betrekking heeft op de 'zorg voor een object' als 'een object van zorg' is. Vooral de eerste betekenis is voor ons betoog relevant. Hieruit komt naar voren dat er 'zorg' moet worden geboden om 'zonder zorg' te kunnen leven. De positieve betekenis van securitas schemert zo duidelijk door: onveiligheid kan niet alleen worden bestreden met nog meer controlemaatregelen. Het gaat tevens om 'zorg voor elkaar' en het stimuleren van onderling vertrouwen.

Het zal duidelijk zijn dat de zelfzuchtige mensvisie van Hobbes en de sociale mensvisie van Aristoteles op gespannen voet met elkaar staan. Juist in deze spanning krijgt het begrip 'veiligheid' een negatieve en positieve betekenis, zonder dat beide betekenissen diametraal tegenover elkaar komen te staan. Wel behoeft het dominante idee dat aan veiligheid alleen een negatief mensbeeld ten grondslag ligt correctie. Gebeurt dat niet, dan blijft de veronderstelling van een oorspronkelijke (burger)oorlog permanent aanwezig in het denken en doen met betrekking tot sociale veiligheid. Anders geformuleerd: hoewel het gebruik van veiligheid in de betekenis van criminaliteit- en overlastbestrijding ('negatieve veiligheid') niet onjuist is, vraagt deze invalshoek om een aanvulling. Het bestrijden van onveiligheid is namelijk iets anders dan het creëren van veiligheid. Beide invalshoeken bedienen zich van een andere taal en andere (beleids)instrumenten. Uitgangspunt van 'positieve veiligheid' in dit alles is dat veiligheidsvertogen zich meer moeten gaan toeleggen op het bevorderen van opbouwende waarden in de samenleving, waaronder geborgenheid, vertrouwen en zorg.

\section{Ethiek en beleid van veiligheid}

Veiligheidsvertogen hoeven niet beperkt te blijven tot traditionele formuleringen van 'bestraffen, verbieden en beboeten'. Sterker nog, deze benadering draagt bij aan een vreemde en onproductieve paradox. Terwijl het uitgangspunt van Hobbes was om een Staat op te richten die de angst voor geweld (criminaliteit, overlast en slachtofferschap) weg moest nemen, wordt dezelfde angst nu aangemoedigd door een Staat die ongebreideld allerhande controle- en surveillancemaatregelen in stelling brengt. Bovendien, en dat is het tweede opvallende punt, leggen criminologen zich vooral toe op het begrijpen van processen die ervoor zorgen dat personen deviant en crimineel gedrag vertonen. Daarentegen gaat het hen veel minder om het blootleggen van beschermende factoren tegen criminaliteit en overlast (vgl. Maruna, 2000). Deze kritiek geldt overigens niet alleen voor de criminologie. Sociale wetenschappen in het algemeen zijn meer geïnteresseerd in pijn, lijden en onderdrukking dan in wat mensen gelukkig maakt, samenbindt en inspireert (Robbins, 2013). Wetenschappers zien met andere woorden vaak datgene over het hoofd wat Ricard de 'banaliteit van het goede' noemt: 'de ontelbare uitingen van solidariteit en hulpvaardigheid die ons dagelijkse bestaan inkleuren en die van grote invloed zijn op de kwaliteit van onze onderlinge omgang' (2015: 116). Volgens Hobbes brengt angst mensen samen. Tegelijk is het omgekeerde natuurlijk ook waar: vertrouwen brengt mensen net zo goed bij elkaar. Vanuit dit perspectief breken processen van positieve veiligheid een lans voor het creëren van een constructieve maatschappelijke context waarbinnen onderling vertrouwen 
mogelijk is, en waaruit onderling vertrouwen ook weer oprijst. Anders dan Gerben Bakker (2015) betoogt, beschouwen wij veiligheid daarom niet als 'in belangrijke mate negatief gefundeerd'. Veiligheid heeft inderdaad sterk negatieve connotaties, maar dat komt vooral omdat positieve discoursen over veiligheid door de geschiedenis heen in de verdrukking zijn gekomen. Het denken vanuit 'negatieve veiligheid' is altijd dominant geweest en heeft andere opvattingen overheerst. Positieve vertogen over veiligheid bouwen dan ook niet voort op negatieve sentimenten, maar geven daar juist tegenwicht aan. Hierdoor verbreedt onze blik zich naar meerdere betekenisvelden van veiligheid die niet per se verenigbaar zijn. In tegenstelling tot bijvoorbeeld de 'Copenhagen School' met hun - tamelijke enge definitie van veiligheid als een 'speech act' (Buzan et al., 1998; Balzacq, 2011) zijn wij vooral geïnteresseerd in concrete technieken en procedures - door Michel Foucault (2008) samengevat onder de term 'gouvernementalité' ('bestuurlijkheid') - die aan het besturen van veiligheid ten grondslag liggen. Hierboven hebben we laten zien dat deze technieken en procedures sterk tenderen naar een negatief ingevuld veiligheidsbeleid (controle, discipline en straf). Daardoor wordt de vraag relevant hoe een positief geïnspireerd veiligheidsbeleid (vertrouwen, geborgenheid en zorg) eruit kan zien. Er bestaat immers een vooralsnog vrijwel onontgonnen gebied dat niet gaat over straf en controle en dat een alternatief biedt voor klassiek hobbessiaans ingestoken sociaal veiligheidsbeleid (vgl. NikolicRistanovic, 2014).

\section{Inhoud themanummer}

Met bovenstaande in het achterhoofd hebben de auteurs die aan dit nummer meedoen zich tot doel gesteld om de term 'positieve veiligheid' van empirische voorbeelden en normatieve reflecties te voorzien. Het eerste artikel van Ronald van Steden gaat over Street Pastors in Cardiff die veiligheid aan uitgaanders bieden door voor hen te zorgen. De pastors brengen jongeren met te veel drank op naar een hotel, hun ouders of een speciale uitslaapplek waar zij niet kwetsbaar zijn voor beroving of verkrachting. Het Street Pastor-team bestaat uit vrijwilligers die vanuit hun christelijke overtuiging tot in de kleine uurtjes de straat op gaan. De pastors laten zien dat veiligheid niet enkel draait om securitas, dat een sterk juridische connotatie heeft gekregen. Er bestaat ook zoiets als certitudo: veiligheid en zekerheid die voortkomen uit het geloof en het (zelf)vertrouwen dat de Street Pastors drijft om naar hun medemens om te zien.

In het tweede artikel toont Jelle Brands op basis van interviews met bezoekers van uitgaansgebieden aan dat veiligheid tijdens een avond uit op een positieve wijze wordt ervaren. Het uitgaan wordt volgens hem onder meer geassocieerd met een prettige, warme, gezellige en ontspannen sfeer. Brands beschrijft de momenten, plekken en situaties waarin positieve veiligheid wordt beleefd en onderscheidt verschillende elementen die daarbij op de voorgrond treden. Het artikel wordt afgesloten met enkele bespiegelingen over het huidige veiligheidsdenken en veiligheidsbeleid in stedelijke uitgaansgebieden. 
In het derde artikel gaat Marc Schuilenburg in op de relatie tussen positieve veiligheid en positieve vrijheid aan de hand van zijn onderzoek naar Buurt Bestuurt in de Rotterdamse wijk Hillesluis. Schuilenburg wijst hierbij op verschillende paradoxen in de participatiemaatschappij. Zo mogen burgers in Buurt Bestuurt meebeslissen welke problemen door politie en gemeente worden opgepakt, maar burgers worden ook gezien als een risico voor de veiligheid en zijn in het dagelijkse leven object geworden van meer surveillance en controle. Op basis van zijn empirische onderzoek naar Buurt Bestuurt stelt Schuilenburg vast dat veel burgers concrete vermogens en vaardigheden missen om de kans (opportunity) die ze wordt geboden om mee te beslissen in het veiligheidsbeleid, ook daadwerkelijk te benutten (exercise).

In het vierde en laatste artikel doen Richard Staring en Mieke Kox verslag van de manier waarop hulpverleningsorganisaties als een safe haven functioneren voor onrechtmatig verblijvende vreemdelingen. Deze vreemdelingen krijgen hier niet alleen materiële hulp als onderdak, leefgeld en voeding, waarmee hun letterlijk een thuis geboden wordt. Zij ontvangen ook verschillende vormen van immateriele ondersteuning. Staring en Kox schrijven dat de 'humanisering' van onrechtmatig verblijvende vreemdelingen door hulpverleningsorganisaties maakt dat de vreemdelingen zich meer gewaardeerd voelen en dat dit hun gezondheid ten goede komt. Hierdoor ontwikkelen vreemdelingen (zelf)vertrouwen en zijn ze beter in staat gebruik te maken van beschikbare medische zorg en van hun rechten. De auteurs wijzen erop dat deze positief opgebouwde veiligheid momenteel onder druk staat, omdat hulpverleningsorganisaties in toenemende mate worden gedwongen om hun hulp aan onrechtmatig verblijvende vreemdelingen te beëindigen. De noodopvang dreigt hiermee hun belangrijke functie als safe haven voor onrechtmatig verblijvende vreemdelingen te verliezen.

In de rubriek Significant Others interviewt René van Swaaningen Jacqueline de Savornin Lohman, voormalig hoogleraar sociale hulpverlening aan de Universiteit van Amsterdam en lid van de Coornhert Liga. In de jaren 1980 heeft zij VOICES, de Vereniging ter Ondersteuning van Initiatieven op het terrein van Criminaliteit En Strafrechtspleging, opgericht. Deze vereniging had onder meer tot doel om positieve initiatieven op strafrechtelijk terrein te initiëren en te ondersteunen. De Savornin Lohman vertelt over haar afkeer van de vrijheidsstraf en wijst erop dat de complexiteit van wat 'criminaliteit' is verdwijnt in de taal waarmee actuele problemen nu worden geduid: een 'war on terrorism', een 'war on drugs' en zelfs een 'war on crime'.

Discussie en debat bestaat uit twee bijdragen. In het eerste stuk over het Nederlandse beleid ten aanzien van jeugd die (dreigt te) ontsporen, stelt Jan Dirk de Jong zich de vraag of positieve veiligheid zich goed verhoudt tot oorlogstaal. Op het eerste gezicht is het antwoord negatief, want staat militaire terminologie niet haaks op het pleidooi voor betrokkenheid, empathie en vertrouwen dat in dit themanummer wordt gehouden? Toch breekt De Jong een lans voor de 'verbindingsofficier' die, in plaats van te strijden, zich moet bezighouden met het leggen van dwarsverbanden tussen jongeren op straat, gepassioneerde rolmodellen die hen op het goede spoor willen houden en de systeemwereld van politici en ambtena- 
ren. Alleen door het zoeken naar verbinding kan positief ingestoken veiligheidsbeleid in de praktijk gestalte krijgen.

Vervolgens belicht Bob Hoogenboom positieve veiligheid vanuit een historisch perspectief. Hij wijst op de wereldberoemde fresco van het goede en het slechte bestuur die in het stadhuis van Sienna te bewonderen valt. Daar hangt securitas positief samen met de rechtszekerheid en rechtvaardigheid die een goed bestuur kenmerken. Voor het Griekse woord politeia - dat we tegenwoordig nog herkennen in 'politiek' en 'politie' - geldt in wezen hetzelfde. Zo ging de Polizeiwissenschaft van oorsprong niet over 'blauw op straat', maar over beleid en bestuur dat algemeen welzijn en collectieve welvaart wilde bevorderen. Vanuit deze traditie kan de herwaardering van positieve veiligheid worden opgevat als een aanzet tot activistisch burgerschap dat tegenwicht moet bieden aan een zich verhardende veiligheidstaal en dito veiligheidsbeleid.

In Voorbij de horizon bespreekt Bas van Stokkom twee recente bundels met dezelfde titel, Positive Criminology, die de 'positive turn' in het veiligheidsdenken tot onderwerp hebben. Van Stokkom wijst op conceptuele onduidelijkheden die de noties 'positieve veiligheid' en 'positieve criminologie' met zich meebrengen. Zo roept 'positieve criminologie' associaties op met de positivistische en deterministische school in de criminologie die de oorzaken van crimineel gedrag buiten de controle van de dader legt. Tegelijk wijst Van Stokkom erop dat 'bescherming tegen schade en slachtofferschap' wel degelijk als positief begrip kan worden opgevat, zoals ook Adam Crawford en Ian Loader duidelijk maken in hun bijdragen aan de bundel Positive Criminology. Reflections on Care, Belonging and Security. Van Stokkom pleit ervoor meer aandacht te besteden aan de stroming peacemaking die volgens hem goede aanknopingspunten biedt voor constructieve benaderingen van conflict en rechtsherstel.

In Doka heeft Yvette Schoenmakers het Centraal Station in Amsterdam gefotografeerd waar sinds 2014 een piano staat waarop iedereen mag spelen. Hiermee verbeeldt ze dat mensen zich veilig, vertrouwd en geborgen voelen op een prettige plaats met een ontspannen atmosfeer.

\section{Literatuur}

Bakker, G. (2015), Positieve veiligheid: een theoretische analyse van een omstreden concept. Tijdschrift voor Veiligheid, 14(2), 36-52.

Balzacq, T. (ed.) (2011), Securitization Theory: How Security Problems Emerge and Dissolve. London: Routledge.

Barnett, J. \& W.N. Adger (2007), Climate change, human security and violent conflict. Political Geography, 26(6), 639-655.

Bauman, Z. (2000), Liquid Modernity. Cambridge: Polity Press.

Beccaria, C. ([1764] 1982), Over misdaden en straffen. Antwerpen: Kluwer.

Bianchi, H. (1958), Waar en waarom misdaad. Amsterdam: N.V. Noordhollandsche Uitgeversmaatschappij.

Boer, M. den \& J. de Wilde (2008), Top-down and bottom-up approaches to human security. In: M. den Boer \& J. de Wilde (eds.), The Viability of Human Security. Amsterdam: Amsterdam University Press, 9-18. 
Buzan, B., O. Wæver \& J. de Wilde (1998), Security: A New Framework for Analysis. Boulder, CO: Rienner.

CBS (2015), Criminaliteit en veiligheidsbeleving: landelijke en regionale trends. Den Haag: Centraal Bureau voor de Statistiek.

Claessen, J. (2015), Over mens- en wereldbeelden en hun bijbehorende misdaadrecht. Justitiële verkenningen, (41)5, 10-31.

Cliteur, P. (2007), Rousseaus kruistocht tegen de beschaving. In: A. Kinneging \& R. Wiche (red.), Van kwaad tot erger: het kwaad in de filosofie. Utrecht: Het Spectrum, 207-227.

Crawford, A. (2011), From the shopping mall to the street corner: dynamics of exclusion in the governance of public space. In: A. Crawford (ed.), International and Comparative Criminal Justice and Urban Governance: Convergence and Divergence in Global, National and Local Settings. Cambridge: Cambridge University Press, 483-518.

Crawford, A. (2014), Thinking about sustainable security: metaphors, paradoxes and ironies. In: M. Schuilenburg, R. van Steden \& B. Oude Breuil (2014), Positive Criminology: Reflections on Care, Belonging and Security. The Hague: Eleven International Publishing, 33-56.

Crawford, A. \& S. Hutchinson (2015), Mapping the contours of 'everyday security': time, space and emotion. The British Journal of Criminology, online first: DOI: 10.1093/bjc/ azv121.

Davis, M. (1992), City of Quartz: Excavating the Future in Los Angeles. New York: Vintage.

Davis, M. (1998), Ecology of Fear: Los Angeles and the Imagination of Disaster. New York: Vintage.

Foucault, M. (1975), Surveiller et punir: naissance de la prison. Paris: Gallimard.

Foucault, M. (2008), The Birth of Biopolitics: Lectures at the Collège de France, 1978-1979. New York: Palgrave Macmillan.

Galtung, J. (1969), Violence, peace and peace research. Journal of Peace Research, 6(3), 167-191.

Gardner, J. (2003), The mark of responsibility. Oxford Journal of Legal Studies, 23(2), 157-171.

Graham, S. (2010), Cities under Siege: The New Military Urbanism. London: Verso.

Hallsworth, S. \& J. Lea (2011), Reconstructing Leviathan: emerging contours of the security state. Theoretical Criminology, 15(2), 141-157.

Hamilton, J.T. (2013), Security: Politics, Humanity and the Philology of Care. Princeton: Princeton University Press.

Hobbes, T. ( [1651] 2007), Leviathan. Amsterdam: Uitgeverij Boom.

Hulsman, L. (2011), Participatie van de gemeenschap bij de preventie van criminaliteit. In: R. van Swaaningen \& J. Blad (red.), De ontmaskering van het strafrechtelijk discours. Een bloemlezing uit het werk van Louk Hulsman, Den Haag: Boom Lemma uitgevers, 195-213.

Hume, D. (2011), The Essential Philosophical Works. Hertfordshire: Wordsworth Editions.

Hutta, J.H. (2008), Geographies of Geborgenheit: beyond feelings of safety and the fear of crime. Environment and Planning D: Society and Space, 27, 251-273.

Krznaric, R. (2014), Empathy: Why it Matters, and How to Get it. London: Random House Group.

Loader, I. \& R. Sparks (2011), Public Criminology?. Routledge: London.

Loader, I. \& N. Walker (2007), Civilizing Security. Cambridge: Cambridge University Press.

Locke, J. (1988), Over het staatsbestuur. Meppel/Amsterdam: Uitgeverij Boom.

Lub, V. (2016), De burger op wacht: het fenomeen 'buurtpreventie' onderzocht. Rotterdam: Bureau voor Sociale Argumentatie. 
Lyon, D. (2001), Surveillance Society: Monitoring Everyday Life. Buckingham: Open University Press.

Marle, F. van (2015), Positieve veiligheid: een kwestie van vertrouwen. Tijdschrift voor Veiligheid, 14(1), 22-33.

Maruna, S. (2002), Making Good: How Ex-Convicts Reform and Rebuild their Lives. Washington: American Psychological Association.

McSweeney, B. (1999), Security, Identity and Interests: A Sociology of International Relations. Cambridge: Cambridge University Press.

Moors, H. \& E. Bervoets (red.) (2013), Frontlijnwerkers in de veiligheidszorg: gevalsstudies, patronen, analyses. Den Haag: Boom Lemma uitgevers.

Neocleous, M. \& G.S. Rigakos (eds.) (2011), Anti-Security. Ottawa: Red Quill Books.

Newman, E. (2016), Human security: reconciling critical aspirations with political 'realities'. British Journal of Criminology, online first.

Nikolic-Ristanovic, V. (2014), Making people happy is the best crime prevention: towards happy-making criminology. European Journal of Criminology, 11(4), 401-409.

Norris, C., M. McCahill \& D. Wood (2002), The growth of CCTV: a global perspective on the international diffusion of video surveillance in publicly accessible space. Surveillance \& Society, 2(2/3), 110-135.

Oosterling, H. (2013), ECO3: doen denken. Heijningen: Japsam Books.

Paris, R. (2011), Human security: paradigm shift or hot air?. International Security, 26(2), 87-120.

Pinker, S. (2011), The Better Angels of our Nature: A History of Violence and Humanity. London: Penguin Books.

Ricard, M. (2015), Altruïsme: de kracht van compassie. Utrecht: Ten Have.

Robbins, J. (2013), Beyond the suffering subject: toward an anthropology of the good. Journal of the Royal Anthropological Institute, 19, 447-462.

Roe, P. (2008), The 'value' of positive security. Review of International Studies, 34(4), 777-794.

Roe, P. (2014), Gender and 'positive security'. International Relations, 28(1), 116-138.

Rousseau, J. ([1755] 2003), Vertoog over de ongelijkheid. Amsterdam: Uitgeverij Boom.

Schuilenburg, M. (2009), De securisering van de samenleving: over de relatie tussen veiligheidszorg, bestuur en quasi-strafrecht. Krisis. Tijdschrift voor actuele filosofie, 3, 6-23.

Schuilenburg, M. (2015), The Securitization of Society: Crime, Risk, and Social Order (with an introduction by David Garland). New York: New York University Press.

Schuilenburg, M. \& C. Dijkstra (2011), Achter de voordeur met stedelijke interventieteams: ontkokering of verkokering?. Justitiële verkenningen, 37(8), 53-71.

Schuilenburg, M. \& R. van Steden (2014a), Praktijken van selectieve uitsluiting: over de bescherming door en tegen veiligheidsassemblages. Cahiers Politiestudies, 30, 51-62.

Schuilenburg, M. \& R. van Steden (2014b), Positive security: a theoretical framework. In: M. Schuilenburg, R. van Steden \& B. Oude Breuil (eds.), Positive Criminology: Reflections on Care, Belonging and Security. The Hague: Eleven International Publishing, 19-32.

Schuilenburg, M. \& R. van Steden (2015), Afgeschermd wonen in Nederland: een studie naar waarom mensen hiervoor kiezen en hoe zij omgaan met interne regelgeving. Tijdschrift voor Veiligheid, 14(3/4), 3-18.

Schuilenburg, M., R. van Steden \& B. Oude Breuil (2014), Positive Criminology: Reflections on Care, Belonging and Security. The Hague: Eleven International Publishing.

Schuilenburg, M. \& R. van Swaaningen (2013), Veiligheid in een laatmoderne cultuur, Tijdschrift over Cultuur \& Criminaliteit, 3(2), 109-122. 
Sennett, R. (2012), Together: The Rituals, Pleasures and Politics of Cooperation. London: Allan Lane.

Steden, R. van (2013), Veelvormige veiligheidszorg: de betrokkenheid van boa's, beveiligers en burgers bij politiewerk. In: E.R. Muller (red.), Veiligheid: studies over inhoud, organisatie en maatregelen (tweede herziene druk). Alphen aan den Rijn: Kluwer, 295-312.

Steden, R. van \& J. Hoogland (red.) (2013), In vertrouwen leven: tegendraadse beschouwingen over veiligheid. Amsterdam: Buijten \& Schipperheijn.

Steden, R. van, M. van Vliet, T. Salman \& H. Boutellier (2010), Gemeenschap als bron van positieve veiligheid: een conceptuele verkenning en aanzet tot empirisch onderzoek. Tijdschrift voor Veiligheid, 9(2), 31-47.

Tops, P. (2011). Regimeverandering in Rotterdam: hoe een stadsbestuur zichzelf opnieuw uitvond. Amsterdam: Atlas.

Waal, F. de (2015), The Age of Empathy: Nature's Lessons for a Kinder Society. New York: Harmony Books.

Wacquant, L. (2008), Urban Outcasts: A Comparative Sociology of Advanced Marginality. Cambridge: Polity Press.

Waever, O. (2008), Peace and security: two evolving concepts and their changing relationship. In: H.G. Brauch et al. (eds.), Globalization and Environmental Challenges: Reconceptualizing Security in the 21st Century, Berlijn/Heidelberg: Springer, 99-112.

Wingerden, S. van (2011), Minimumstraffen en de dovemansorden van de wetgever. Proces, 90(6), 322-333.

Wood, J. \& C. Shearing (2009), De nodale politiefunctie. Justitiële verkenningen, 1, 11-28.

Young, J. (1999), The Exclusive Society: Social Exclusion, Crime and Difference in Late Modernity. London: Sage.

Zedner, L. (2009), Security. London: Routledge.

Zuijlen, R.W. van (2008), Veiligheid als opdracht: een onderzoek naar veiligheid als fundamenteel recht en als positieve verplichting van de staat in het licht van de politietaak tot strafrechtelijke rechtshandhaving. Nijmegen: Wolf Legal Publishers. 